\title{
A Maurer's cleft-associated Plasmodium falciparum membrane-associated histidine-rich protein peptide specifically interacts with the erythrocyte membrane
}

\author{
Jeison García ${ }^{\text {a }}$, Hernando Curtidor ${ }^{\mathrm{a}, \mathrm{b}}$, Olga L. Gil a , Magnolia Vanegas ${ }^{\mathrm{a}, \mathrm{b}}$, Manuel E. Patarroyo ${ }^{\mathrm{a}, *}$ \\ ${ }^{a}$ Fundación Instituto de Inmunología de Colombia, Carrera 50, No. 26-00, Bogotá, Colombia \\ ${ }^{\mathrm{b}}$ Universidad del Rosario, Calle 14, No. 6-25, Bogotá, Colombia
}

\section{A R T I C L E I N F O}

\section{Article history:}

Received 19 December 2008

Available online 21 January 2009

\section{Keywords:}

Antimalarial candidate

High-activity binding peptide

MAHRP-1

Malaria

Maurer's clefts

Plasmodium falciparum

\begin{abstract}
A B S T R A C T
The membrane-associated histidine-rich protein-1 (MAHRP-1) is a Maurer's cleft-resident molecule that has been recently described as an important protein for the trafficking of PfEMP-1 to infected erythrocyte membrane, a major virulence factor. We have studied the specific interactions between 20-mer-long synthetic peptides spanning the complete MAHRP-1 sequence and erythrocytes. A high-activity binding peptide (HABP) with saturable binding to a $46-\mathrm{kDa}$ erythrocyte membrane protein was identified and its binding was affected by chymotrypsin treatment. Random coil and $\alpha$-helical features were found in the HABP's structure. Our results suggest that MAHRP-1 specifically interacts with erythrocyte membrane through a 20-mer-long amino acid region, raising questions about this region's potential as a therapeutic target against malaria.
\end{abstract}

(c) 2009 Elsevier Inc. All rights reserved.
Malaria caused by Plasmodium remains one of the most important world health problems as it accounts for 500 million cases and more than 3 million deaths per year [1]. Some of the most severe malaria pathologies (anemia, cerebral and placental malaria, among others) have been associated to infection with Plasmodium falciparum and specifically linked to the parasite's intra-erythrocytic developmental stage resulting in the adherence of infected erythrocytes (IE) to capillary vessels and to normal erythrocytes; two phenomena respectively named cytoadherence [2] and rosseting $[3,4]$.

Parasite proteins exported to the host-cell membrane such as the $\boldsymbol{P}$. falciparum erythrocyte membrane protein-1 (PfEMP-1) family and the knob-associated histidine-rich protein (KAHRP) have been target of extensive study due to their role in cytoadherence and rosseting phenomena. Even thought the latter protein is located on the cytoplasmatic face of IE knobs, monoclonal and polyclonal anti-KAHRP antibodies are known to disrupt rosette formation, suggesting that the presence of anti-rosseting antibodies in human sera is associated with protection against cerebral malaria and thus, that this intracellular protein might also be an attractive antimalarial immunoprophylactic target [5-8].

In addition to KAHRP, other intracellular P. falciparum proteins expressed by parasite erythrocyte's invasive stages have been shown to be important candidates for an antimalarial vaccine, as

\footnotetext{
* Corresponding author. Fax +57 14815269.

E-mail address: mepatarr@mail.com (M.E. Patarroyo).
}

for instance the $P$. falciparum ribosomal phosphoprotein P0 (PfP0), which has shown to induce production of polyclonal antibodies capable of blocking parasite invasion to erythrocytes [9] and whose $P$ domain has protected mice against challenge with Plasmodium yoelii [10]. Together, these results highlight the importance of studying molecules involved, either directly or indirectly, in parasite survival since they could be promising targets for new and totally protective methods against $P$. falciparum infection.

Plasmodium falciparum replication inside erythrocytes evolves from ring, to trophozoites and to schizont stages. Ring stages are characterized by having low metabolic and biosynthetic activity with no significant changes in the IE structure. In contrast, rapid growth and multiplication together with sequestration of IE is observed in trophozoite and schizont stages, finalizing with IE rupture and liberation of new merozoites $[4,11,12]$. These observations suggest that critical changes are needed for the successful development and reproduction of the parasite inside host cells during early stages of the intra-erythrocytic cycle, and stress the importance of proteins exported to IE during these stages as potential targets for developing new antimalarial strategies.

Among parasite-exported molecules is a $28.9 \mathrm{kDa}$ protein consisting of a highly conserved $\mathrm{N}$-terminal region, a putative transmembrane domain in its middle region, and a variable histidinerich domain containing several DHGH amino acid sequence repeats at its C-terminal end [13]. This membrane-associated histidinerich protein (MAHRP-1) is expressed during early stages of $P$. falciparum intra-erythrocytic development and has been located at the 
Maurer's clefts (MCs), which are important organelles involved in trafficking of several proteins towards IE membrane, including PfEMP-1, KAHRP and other important virulence factors [3,4,1416]. The MAHRP-1 N-terminal region together with its transmembranal domain have been reported as being fundamental for the proper exportation of this protein toward MCs [17], since no signal peptide nor classical $\boldsymbol{P}$. falciparum export elements (PEXEL) type motifs have been identified in its amino acid sequence. These reports suggest that MAHRP-1 is exported through alternative trafficking pathways non-dependent of the classical PEXEL motif $[17,18]$.

MAHRP-1 has not been assigned a concrete functional role yet. It has been reported that MAHRP-1 binds to the heme component of hemoglobin, named ferriprotoporphyrin IX [13], which results from the parasite's digestion of hemoglobin to obtain essential amino acids for its survival and is stored as a pigment called hemozoine. Several other parasite HRPs have been also involved in hemoglobin degradation, including the HRPs II and III $[19,20]$. These observations have suggested a possible relationship between MAHRP-1 and hemozoine production, although no evidence exists to date to confirm such connection. Additionally, MAHRP-1 has been described as being essential for the translocation of PfEMP1 to the IE surface, an important mediator of IE cytoadherence to host-cell membrane receptors [21].

Interestingly, when the mahrp-1 gene is disrupted, no effect on MC formation is evidenced, however, they become disorganized in IEs [21]. These results suggest that MAHRP-1 might be fulfilling a functional rather than a structural role in MCs.

Our institute has developed and thoroughly described [22] a highly robust, specific and sensitive methodology suitable for recognizing binding sequences in parasite proteins involved in invasion to host cells or in cytoadherence phenomena [6,23-28]; and which has served to identify new potential components of a minimal sub-unit based, multi-epitopic, multi-stage synthetic antimalarial vaccine. In this work, we have identified a MAHRP-1 erythrocyte high-activity binding peptide (HABP) and characterized its binding interaction through saturation assays, cross-linking to erythrocyte membrane proteins, binding to enzymetreated cells, invasion inhibition of erythrocytes and structural analysis by circular dichroism. The results of this study, added to the importance of HRPs in P. falciparum intra-erythrocytic development, support the inclusion of this MAHRP-1 HABP in future immunological studies aiming at evaluating its potential as a component of new and more effective immunoprophylactic methods against $P$. falciparum malaria.

\section{Materials and methods}

Peptide synthesis and binding assays. Thirteen 20-mer non-overlapping peptides covering the complete P. falciparum MAHRP-1 amino acid sequence (MAL13P1.413) [13] were synthesized by solid-phase multiple peptide system ( $t$-Boc strategy) and cleaved by low-high techniques [29-31]. The peptides were purified by RPHPLC and then characterized by MALDI-TOF mass spectrometry (data not shown). One Tyr residue was added at the C-terminal of those peptides not containing this residue in their native sequence to enable ${ }^{125}$ I-radio-labeling. Purified peptides $(2 \mathrm{nmol}$ ) were then labeled with $5 \mu \mathrm{L}{ }^{125} \mathrm{I}-\mathrm{Na}(100 \mathrm{mCi} / \mathrm{mL}, \mathrm{ICN})$ and $0.3 \mu \mathrm{mol}$ chloramine-T at a final $20 \mu \mathrm{L}$ volume in 15 min reactions; stopping reactions with $0.3 \mu \mathrm{mol}$ sodium metabisulfite. The ${ }^{125} \mathrm{I}-$ radio-labeled peptides were then purified using a Sephadex G-10 column (Pharmacia) $(100 \times 5 \mathrm{~mm})$ and measured on an automatic gamma counter (Packard Cobra II) [25,27].

For erythrocyte binding assays, $1 \times 10^{8}$ cells were incubated for 90 min with increasing concentrations $(0-560 \mathrm{nM})$ of ${ }^{125}$ I-peptide in the presence (non-specific binding) or absence (total binding) of unlabelled peptide $(4 \mathrm{nmol})$. Cells were then washed twice with HBS buffer and their associated radioactivity was quantified in an automatic gamma counter. [25,27] All assays were carried out in triplicate. Data were analyzed taking into account that the difference between total binding and non-specific binding represented the peptide's specific binding to erythrocytes. A peptide having a $\geqslant 2 \%$ slope between specific binding and added ${ }^{125}$ I-peptide was considered a high-activity binding peptide (HABP), according to previously established criteria [22,24,25,27]. Peptide 33769 showed a $3.9 \%$ high specific binding activity to erythrocytes and therefore was considered a HABP.

MAHRP-1 HABP saturation assay. To determine the kinetic constants of MAHRP-1 HABP binding, 15\% hematocrit suspensions of erythrocytes were incubated with concentrations of radio-labeled HABP in triplicate $\left({ }^{125} \mathrm{I}-\mathrm{HABP}\right)$ starting at 0 and up to $2600 \mathrm{nM}$, in the presence or absence of unlabelled peptide $(6 \mathrm{nmol})$. Cells were then washed with HBS before measuring the cell-associated radioactivity in a gamma counter. The dissociation constant $\left(K_{d}\right)$, binding sites per cell (BSC) and Hill coefficient $(n H)$ were calculated by analyzing the saturation curve $[6,24]$.

Effect of the enzymatic treatment on HABP binding to erythrocytes. For these assays, erythrocytes at a $60 \%$ hematocrit were suspended in HBS and independently treated with $150 \mu \mathrm{U} / \mathrm{mL}$ neuraminidase (ICN 9001-67-6), trypsin (Sigma T-1005) or chymotrypsin (Sigma $\mathrm{C}-4129$ ) at a final $1 \mathrm{mg} / \mathrm{mL}$ concentration for $1 \mathrm{~h}$ at $37^{\circ} \mathrm{C}$. Samples were then spun at $2000 \times g$ for 3 min and washed thrice with HBS. Treated erythrocytes were tested following conventional binding assays with HABP [23]. The results showed a decrease of more than $60 \%$ in conserved HABP binding to chymotrypsin-treated erythrocytes, which suggest an integral erythrocyte membrane protein as the receptor molecule of this HABP.

HABP cross-linking to its erythrocyte membrane receptor. Following a conventional binding assay with the identified HABP, ${ }^{125} \mathrm{I}-$ HABP-erythrocyte membrane proteins were cross-linked with $100 \mu \mathrm{L}$ bis-sulfosuccinimidyl suberate (BS ${ }^{3} 1 \mathrm{mg} / \mathrm{mL}$-PIERCE) for $30 \mathrm{~min}$ at $4{ }^{\circ} \mathrm{C}$. Once this time had elapsed, the reaction was stopped with $25 \mathrm{mM}$ Tris- $\mathrm{HCl}$ ( $\mathrm{pH}$ 7.4) and cells were washed thrice with HBS. Samples were then treated with $15 \mu \mathrm{L}$ lysis buffer (5\% SDS, $10 \mathrm{nM}$ iodoacetamide, 1\% Triton X-100, $100 \mathrm{mM}$ EDTA, and $10 \mathrm{mM}$ PMSF) and $15 \mu \mathrm{L}$ Laemmli buffer was added. Erythrocyte membranes were pelleted at $15000 \times \mathrm{g}$ for $10 \mathrm{~min}$ and the supernatant containing extracted proteins was separated by $12 \%$ SDS-PAGE, subsequently auto-radiographically developed on a Kodak film (X-OMAT) and kept at $70{ }^{\circ} \mathrm{C}$ for $10-20$ days. The molecular weight of the labeled band was determined by comparing the migration distance of molecular weight markers (Fermentas Life Science) [24].

MAHRP-1 HABP secondary structure features. Circular dichroism (CD) spectrum were obtained for the MAHRP-1 HABP to determine its main structural features. CD spectrum was recorded in $30 \%$ trifluoroethanol (TFE)/water at $20^{\circ} \mathrm{C}$ on a Jasco J-810 spectropolarimeter at wavelengths ranging from 260 to $190 \mathrm{~nm}$ using $1.00-\mathrm{cm}$ optical path cuvettes [32]. The results were expressed as mean residue ellipticity $(\Theta)$, being the units degrees $\times \mathrm{cm}^{2} \times \mathrm{dmol}^{-1}$ according to the $[\Theta]=\Theta \cdot \lambda /(100 \cdot l \cdot c \cdot n)$ function, where $\Theta \cdot \lambda$ corresponds to the measured ellipticity, $l$ to the optical path-length, $c$ to the peptide concentration and $n$ to the number of amino acid residues contained in the sequence. Deconvolution of the obtained spectrum was performed using SELCON, CONTINLL, and CDSSTR programs [32,33].

Inhibition of merozoite invasion. Sorbitol-synchronized P. falciparum cultures (FCB-2 strain) [34] were incubated until late-schizogony at a final $0.5 \%$ parasitemia and $5 \%$ hematocrit in RPMI $1640+10 \%$ O positive plasma. Cultures were then seeded in 96well cell-culture plates in the presence of the tested peptide 
$(200 \mu \mathrm{M})$ in triplicate. Supernatants were recovered after an $18 \mathrm{~h}$ incubation period at $37{ }^{\circ} \mathrm{C}$ in $5 \% \mathrm{O}_{2}, 5 \% \mathrm{CO}_{2}$, and $90 \% \mathrm{~N}_{2}$ atmosphere. Erythrocytes were stained with $15 \mu \mathrm{g} / \mathrm{mL}$ hydroethidine, incubated at $37^{\circ} \mathrm{C}$ for $30 \mathrm{~min}$ and then washed thrice with PBS. The suspensions were analyzed by flow cytometry (FACsort) in Log FL2 data-mode, using CellQuest software (Becton-Dickinson immunocytometry system, San Jose, CA) [35]. Infected and uninfected erythrocytes, and infected human erythrocytes treated with EGTA and chloroquine were used as controls.

\section{Results and discussion}

In this work, once the whole MAHRP-1 sequence was chemically synthesized, binding assays were carried out in order to determine which of the twelve 20-mer-long non-overlapping synthetic peptides presented high specific erythrocyte binding activity. Peptide $33769\left({ }^{21}\right.$ ADVPTEGMDVPFGFFDKNTLY $\left.{ }^{40}\right)$ located at the MAHRP's conserved N-terminal region was the only one showing such behavior (Fig. 1). This HABP's localization inside a conserved region has important significance given that conserved HABPs are not antigenic, nor immunogenic or protection inducers and therefore, modifications in the critical binding residues of these, immunologically-silent conserved HABPs have proven to induce production of long-lasting antibody titers against $P$. falciparum parasites and protection against experimental challenge with a highly infectious Aotus-adapted P. falciparum strain [6,36-38]. In addition, the saturation assay (Fig. 2) carried out with this HABP established that its binding is saturable, with a $K_{d}$ in the nanomolar range (900 $\mathrm{nM}$ ), a $n \mathrm{H}$ equal to 1 and around $300000 \mathrm{BSC}$

Our results indicate that the MAHRP-1 HABP 33769 is directly involved in this protein's interaction with erythrocyte membrane receptors. Spycher et al. [17] have reported that the region lying between residues 52-169 is sufficient for the proper trafficking of MAHRP-1 to MCs. Once MAHRP-1 is in MCs, another MAHRP-1 region(s) is possibly in charge of interacting with the IE membrane receptor(s) [21]. These observations lead us to suggest that HABP 33769 is possibly present in the MAHRP-1 region that associates with IE and that it fulfills a structural role in MCs. However, additional studies are needed to further support to this statement.

The nature of erythrocyte membrane receptor(s) for this peptide was examined in HABP binding assays with enzymatically

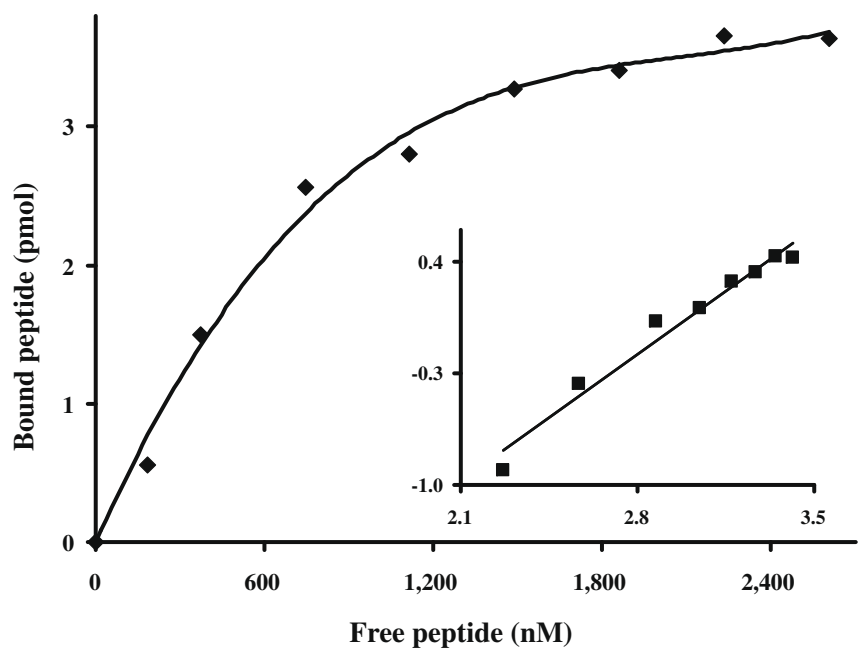

Fig. 2. Saturation curve of HABP 33769. The curve represents specific binding. In the Hill plot (inset), $\log F$ is the abscissa and $\log \left(B / B_{\max }-B\right)$ the ordinate, being $\mathrm{F}$ the amount of free peptide, $B$ the amount of bound peptide and $B_{\max }$ the maximum amount of bound peptide.

treated erythrocytes (Fig. 3a), finding that HABP 33769's specific binding was reduced to $59 \%$ when erythrocytes were treated with chymotrypsin; whereas binding was not affected when trypsin- or neuraminidase-treated erythrocytes were used in these assays, suggesting a erythrocyte receptor of proteic nature for this HABP. The apparent molecular weight of the erythrocyte membrane receptor interacting with MAHRP-1 HABP was determined in a cross-linking assay. The autoradiography (Fig. $3 \mathrm{~b}$ ) showed that HABP 33769 binds specifically to a 46-kDa erythrocyte surface protein. These results suggest an erythrocyte membrane protein such as the previously described putative receptor " $Z$ " [39].

The CD spectrum obtained for HABP 33769 revealed the presence of $\alpha$-helix structural elements and random coil features in this HABP's secondary structure, indicated by the slight displacement of the characteristic $190 \mathrm{~nm}$ maximum, and 208 and $220 \mathrm{~nm}$ minima (Fig. 4). Spectrum deconvolution confirmed the above observations since it showed $40 \% \alpha$-helical content and a $60 \%$ content of random coil and $\beta$-turn features in HABP 33769 structure, being

\begin{tabular}{|c|c|c|c|c|}
\hline $\begin{array}{l}\text { Peptide } \\
\text { number }\end{array}$ & \multicolumn{3}{|c|}{ MAHRP-1 } & ${ }_{2}$ Specific Binding Activity (\%) \\
\hline 33768 & 1 & $\begin{array}{lllllllllllllllllllll}M & A & E & Q & A & A & V & Q & P & E & S & V & P & T & V & G & T & V & P & Q & Y \\
\end{array}$ & 20 & I \\
\hline 33769 & 21 & 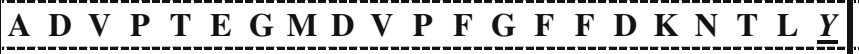 & 40 & \\
\hline 33770 & 41 & $\begin{array}{lllllllllllllllllllllll}K & K & L & M & F & I & F & M & R & D & V & D & N & Y & A & R & N & W & F & T\end{array}$ & 60 & I \\
\hline 33771 & 61 & 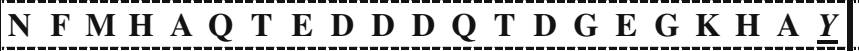 & 80 & I \\
\hline 33772 & 81 & 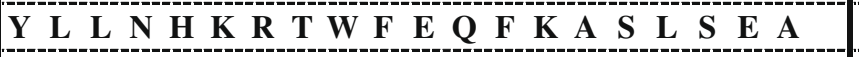 & 100 & I \\
\hline 33773 & -101 & 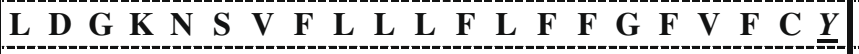 & 120 & I \\
\hline 33774 & 121 & 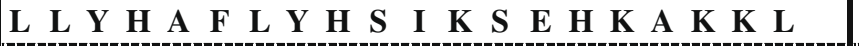 & 140 & I \\
\hline 33775 & 141 & 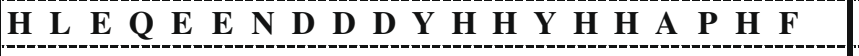 & 160 & 1 \\
\hline 33776 & 161 & Y P F F D P E Y M H D H D H D H E H D H & 180 & I \\
\hline 33777 & 181 & 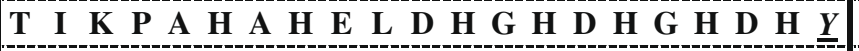 & 200 & I \\
\hline 33778 & 201 & 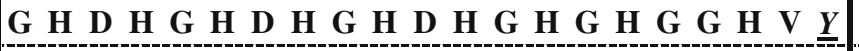 & 220 & 1 \\
\hline 33779 & 221 & 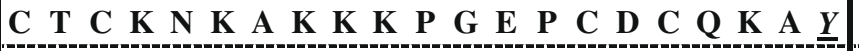 & 240 & I \\
\hline 33780 & 241 & 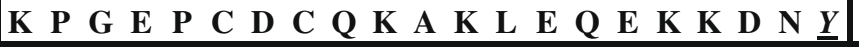 & 260 & I \\
\hline
\end{tabular}

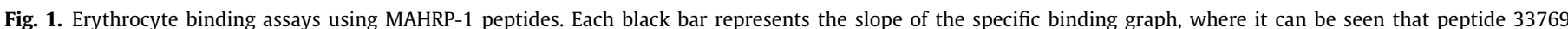

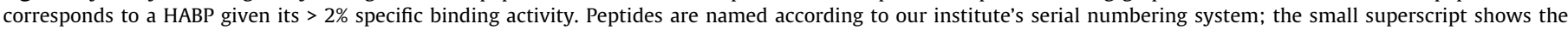
position of the peptide in the protein's amino acid sequence. Additionally, a structural model of MAHRP- 1 is shown at the left side of the profile. 


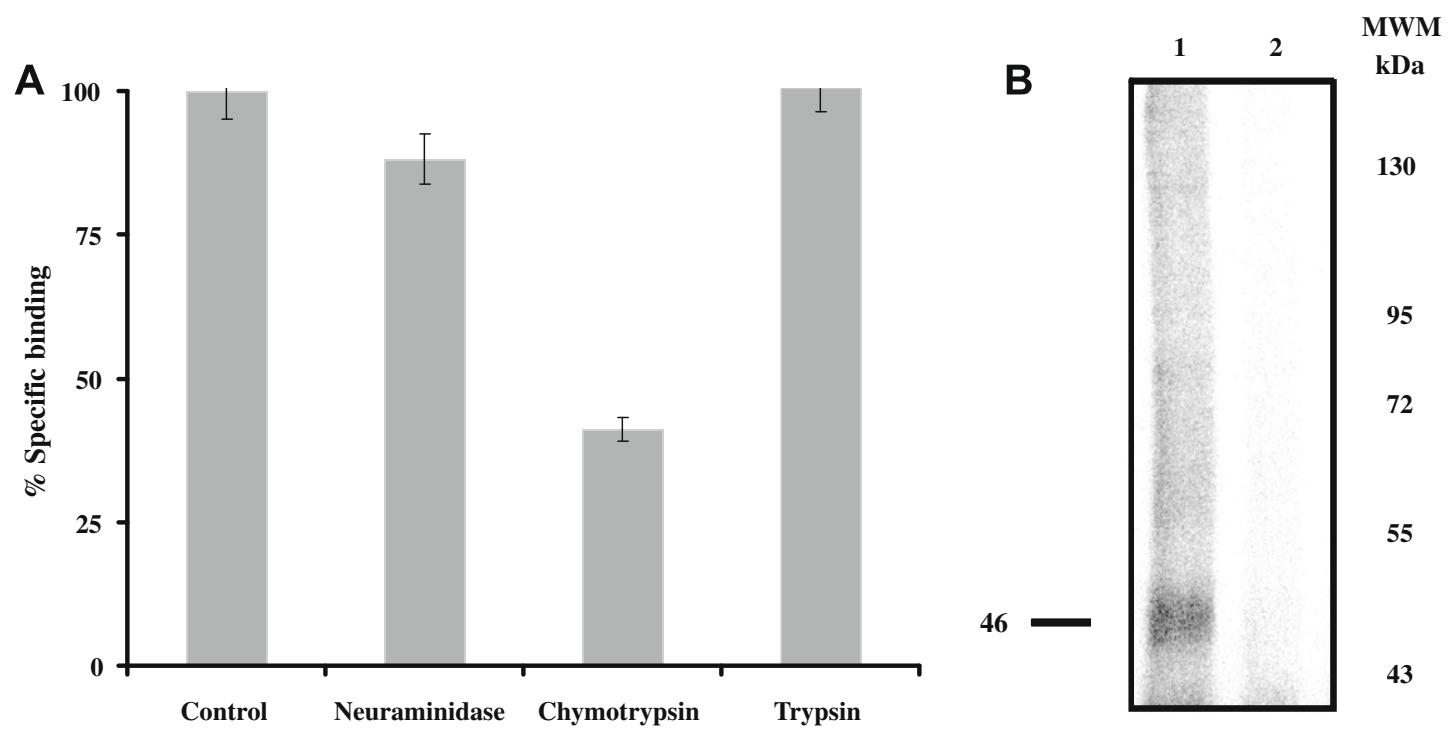

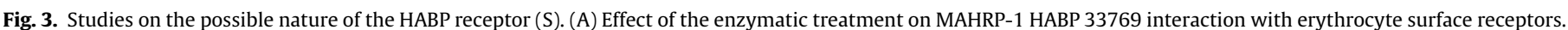

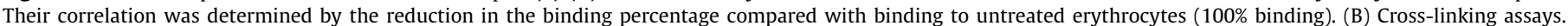

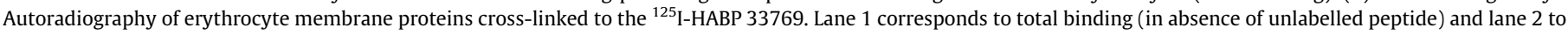
non-specific binding (in presence of unlabelled peptide), showing the specificity of HABP-erythrocyte interaction with a 46-kDa erythrocyte molecule.
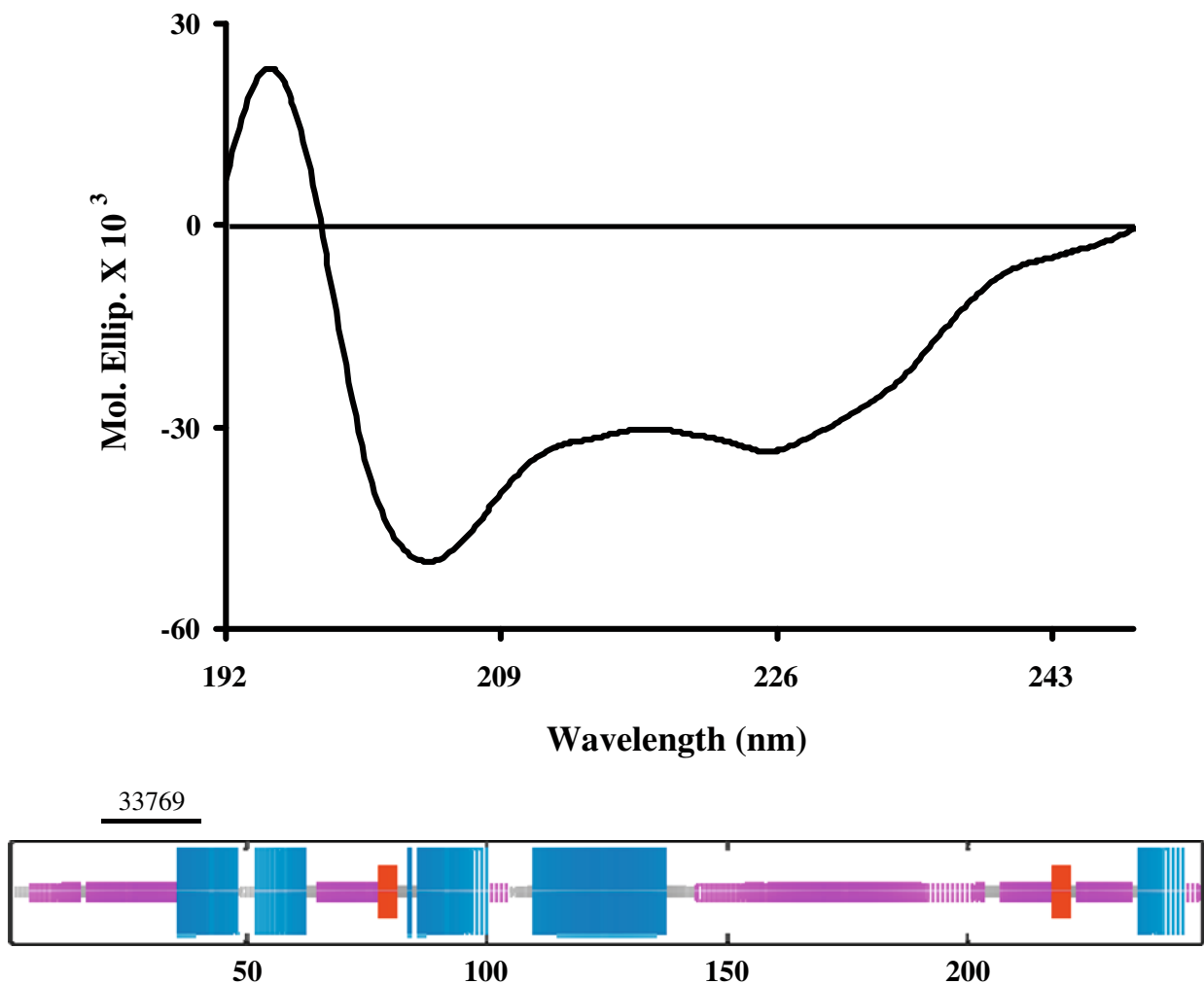

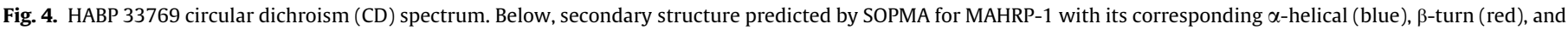
random coil (fuchsia) features.

these structural features consistent with the secondary structure prediction by NPS@ Self Optimized Prediction Method from Alignment (SOPMA) server [40]. A functional compartmentalization of $P$. falciparum proteins has been previously described, showing that proteins having a high content of $\beta$-turn or random coil structures are generally bound to the merozoite membrane via glycosylphosphatidylinositol (GPI) anchoring tails, or they contain PEXEL motifs or transmembranal sequences being this latter the case of MAHRP-
1 , since a transmembranal sequence is predicted in its structure between residues 106 and 128 [41].

Additionally, the biological role of MAHRP-1 HABP was evaluated in vitro through a merozoite invasion inhibition assay using sorbitol-synchronized $P$. falciparum cultures. Interestingly, HABP 33769 inhibited erythrocyte's invasion by $30 \pm 3 \%$ at a $200 \mu \mathrm{M}$ peptide concentration, whereas controls (low activity binding peptides 33768 and 33778) had no inhibitory effect. Even though MAHRP-1 
is involved in the parasite intra-erythrocytic development, this result indicates that MAHRP-1 HABP 33769 could be interacting with high specificity and saturability with a 46-kDa erythrocyte membrane protein and partially inhibiting parasite infection of host cells through such interaction.

These findings support the inclusion of this conserved N-terminal HABP in future biological and immunological studies to further elucidate the molecular mechanism involved in P. falciparum lifecycle development with the aim of identifying new candidates to be included in a minimal sub-unit-based, multi-stage, multi-epitopic, chemically synthesized antimalarial vaccine $[7,8,42]$.

\section{Acknowledgments}

This study was supported by COLCIENCIAS, contract RC-2008. We thank Nora Martinez for translating the paper.

\section{References}

11] R.W. Snow, C.A. Guerra, A.M. Noor, H.Y. Myint, S.I. Hay, The global distribution of clinical episodes of Plasmodium falciparum malaria, Nature 434 (2005) 214217.

[2] N. Rasti, M. Wahlgren, Q. Chen, Molecular aspects of malaria pathogenesis, FEMS Immunol. Med. Microbiol. 41 (2004) 9-26.

[3] B.M. Cooke, K. Lingelbach, L.H. Bannister, L. Tilley, Protein trafficking in Plasmodium falciparum-infected red blood cells, Trends Parasitol. 20 (2004) 581-589.

[4] L. Tilley, G. McFadden, A. Cowman, N. Klonis, Illuminating Plasmodium falciparum-infected red blood cells, Trends Parasitol. 23 (2007) 268-277.

[5] Q. Chen, The naturally acquired immunity in severe malaria and its implication for a PfEMP-1 based vaccine, Microbes Infect. 9 (2007) 777-783.

[6] H. Curtidor, M.H. Torres, M.P. Alba, M.E. Patarroyo, Structural modifications to a high-activity binding peptide located within the PfEMP1 NTS domain induce protection against $P$. falciparum malaria in Aotus monkeys, Biol. Chem. 388 (2007) 25-36.

[7] J. Carlson, H. Helmby, A. Hill, D. Brewster, B.M. Greenwood, M. Wahigren, Human cerebral malaria: association with erythrocyte rosetting and lack of anti-rosetting antibodies, Lancet 336 (1990) 1457-1460.

[8] J. Carlson, G. Holmquist, D.W. Taylor, P. Perlman, M. Wahlgren, Antibodies to a histidine rich protein (PfHRP-I) disrupt spontaneously formed Plasmodium falciparum erythrocyte rosettes, Proc. Natl. Acad. Sci. USA 87 (1990) 25112515.

[9] S. Chatterjee, S. Singh, R. Sohoni, V. Kattige, C. Deshpande, S. Chiplunkar, N. Kumar, S. Sharma, Characterization of domains of the phosphoriboprotein P0 of Plasmodium falciparum, Mol. Biochem. Parasitol. 107 (2000) 143-154.

[10] K. Rajeshwari, K. Patel, S. Nambeesan, M. Mehta, A. Sehgal, T. Chakraborty, S. Sharma, The P domain of the P0 protein of Plasmodium falciparum protects against challenge with malaria parasites, Infect. Immun. 72 (2004) 5515-5521.

[11] P.L. Hawthorne, K.R. Trenholme, T.S. Skinner-Adams, T. Spielmann, K. Fischer, M.W. Dixon, M.R. Ortega, K.L. Anderson, D.J. Kemp, D.L. Gardiner, A novel Plasmodium falciparum ring stage protein, REX, is located in Maurer's clefts, Mol. Biochem. Parasitol. 136 (2004) 181-189.

[12] T. Spielmann, P.L. Hawthorne, M.W. Dixon, M. Hannemann, K. Klotz, D.J. Kemp, N. Klonis, L. Tilley, K.R. Trenholme, D.L. Gardiner, A cluster of ring stagespecific genes linked to a locus implicated in cytoadherence in Plasmodium falciparum codes for PEXEL-negative and PEXEL-positive proteins exported into the host cell, Mol. Biol. Cell 17 (2006) 3613-3624.

[13] C. Spycher, N. Klonis, T. Spielmann, E. Kump, S. Steiger, L. Tilley, H.P. Beck, MAHRP-1, a novel Plasmodium falciparum histidine-rich protein, binds ferriprotoporphyrin IX and localizes to the Maurer's clefts, J. Biol. Chem. 278 (2003) 35373-35383.

[14] B.M. Cooke, D.W. Buckingham, F.K. Glenister, K.M. Fernandez, L.H. Bannister, M. Marti, N. Mohandas, R.L. Coppel, A Maurer's cleft-associated protein is essential for expression of the major malaria virulence antigen on the surface of infected red blood cells, J. Cell Biol. 172 (2006) 899-908.

[15] M. Lanzer, H. Wickert, G. Krohne, L. Vincensini, C. Braun Breton, Maurer's clefts: a novel multi-functional organelle in the cytoplasm of Plasmodium falciparum-infected erythrocytes, Int. J. Parasitol. 36 (2006) 23-36.

[16] J.M. Przyborski, H. Wickert, G. Krohne, M. Lanzer, Maurer's clefts - a novel secretory organelle?, Mol Biochem. Parasitol. 132 (2003) 17-26.

[17] C. Spycher, M. Rug, N. Klonis, D.J. Ferguson, A.F. Cowman, H.P. Beck, L. Tilley, Genesis of and trafficking to the Maurer's clefts of Plasmodium falciparuminfected erythrocytes, Mol. Cell. Biol. 26 (2006) 4074-4085.

[18] P. Horrocks, D. Muhia, Pexel/VTS: a protein-export motif in erythrocytes infected with malaria parasites, Trends Parasitol. 21 (2005) 396-399.
[19] A. Lynn, S. Chandra, P. Malhotra, V.S. Chauhan, Heme binding and polymerization by Plasmodium falciparum histidine rich protein II: influence of pH on activity and conformation, FEBS Lett. 459 (1999) 267-271.

[20] D.J. Sullivan Jr., I.Y. Gluzman, D.E. Goldberg, Plasmodium hemozoin formation mediated by histidine-rich proteins, Science 271 (1996) 219-222.

[21] C. Spycher, M. Rug, E. Pachlatko, E. Hanssen, D. Ferguson, A.F. Cowman, L. Tilley, H.P. Beck, The Maurer's cleft protein MAHRP1 is essential for trafficking of PfEMP1 to the surface of Plasmodium falciparum-infected erythrocytes, Mol. Microbiol. 68 (2008) 1300-1314.

[22] L.E. Rodriguez, H. Curtidor, M. Urquiza, G. Cifuentes, C. Reyes, M.E. Patarroyo Intimate molecular interactions of $P$. falciparum merozoite proteins involved in invasion of red blood cells and their implications for vaccine design, Chem. Rev. 108 (2008) 3656-3705.

[23] H. Curtidor, M. Urquiza, J.E. Suarez, L.E. Rodriguez, M. Ocampo, A. Puentes, J.E. Garcia, R. Vera, R. Lopez, L.E. Ramirez, M. Pinzon, M.E. Patarroyo, Plasmodium falciparum acid basic repeat antigen (ABRA) peptides: erythrocyte binding and biological activity, Vaccine 19 (2001) 4496-4504.

[24] C.G. Pinzon, H. Curtidor, A. Bermudez, M. Forero, M. Vanegas, J. Rodriguez, M.E. Patarroyo, Studies of Plasmodium falciparum rhoptry-associated membrane antigen (RAMA) protein peptides specifically binding to human RBC, Vaccine 26 (2008) 853-862.

[25] L.E. Rodriguez, M. Urquiza, M. Ocampo, J. Suarez, H. Curtidor, F. Guzman, L.E Vargas, M. Trivinos, M. Rosas, M.E. Patarroyo, Plasmodium falciparum EBA$175 \mathrm{kDa}$ protein peptides which bind to human red blood cells, Parasitology 120 (Pt. 3) (2000) 225-235.

[26] L.E. Rodriguez, R. Vera, J. Valbuena, H. Curtidor, J. Garcia, A. Puentes, M. Ocampo, R. Lopez, J. Rosas, Y. Lopez, M.A. Patarroyo, M.E. Patarroyo, Characterisation of Plasmodium falciparum RESA-like protein peptides that bind specifically to erythrocytes and inhibit invasion, Biol. Chem. 388 (2007) 15-24.

[27] M. Urquiza, L.E. Rodriguez, J.E. Suarez, F. Guzman, M. Ocampo, H. Curtidor, C. Segura, E. Trujillo, M.E. Patarroyo, Identification of Plasmodium falciparum MSP-1 peptides able to bind to human red blood cells, Parasite Immunol. 18 (1996) 515-526.

[28] R. Vera Bravo, V. Marin, J. Garcia, M. Urquiza, E. Torres, M. Trujillo, J. Rosas, M.E. Patarroyo, Amino terminal peptides of the ring infected erythrocyte surface antigen of Plasmodium falciparum bind specifically to erythrocytes, Vaccine 18 (2000) 1289-1293.

[29] R.A. Houghten, General method for the rapid solid-phase synthesis of large numbers of peptides: specificity of antigen-antibody interaction at the level of individual amino acids, Proc. Natl. Acad. Sci. USA 82 (1985) 5131-5135.

[30] R.B. Merrifield, Solid phase peptide synthesis. I. The synthesis of a tetrapeptide, J. Am. Chem. Soc. 85 (1963) 2149-2154.

[31] J.P. Tam, W.F. Heath, R.B. Merrifield, SN 1 and SN 2 mechanisms for the deprotection of synthetic peptides by hydrogen fluoride. Studies to minimize the tyrosine alkylation side reaction, Int. J. Pept. Protein Res. 21 (1983) 57-65.

[32] N. Sreerama, S.Y. Venyaminov, R.W. Woody, Estimation of the number of alpha-helical and beta-strand segments in proteins using circular dichroism spectroscopy, Protein Sci. 8 (1999) 370-380.

[33] N. Sreerama, R.W. Woody, Estimation of protein secondary structure from circular dichroism spectra: comparison of CONTIN, SELCON, and CDSSTR methods with an expanded reference set, Anal. Biochem. 287 (2000) 252260.

[34] C. Lambros, J.P. Vanderberg, Synchronization of Plasmodium falciparum erythrocytic stages in culture, J. Parasitol. 65 (1979) 418-420.

[35] C.R. Wyatt, W. Goff, W.C. Davis, A flow cytometric method for assessing viability of intraerythrocytic hemoparasites, J. Immunol. Methods 140 (1991) 23-30.

[36] A. Bermudez, G. Cifuentes, F. Guzman, L.M. Salazar, M.E. Patarroyo, Immunogenicity and protectivity of Plasmodium falciparum EBA-175 peptide and its analog is associated with alpha-helical region shortening and displacement, Biol. Chem. 384 (2003) 1443-1450.

[37] M. Cubillos, L.M. Salazar, L. Torres, M.E. Patarroyo, Protection against experimental P. falciparum malaria is associated with short AMA-1 peptide analogue alpha-helical structures, Biochimie 84 (2002) 1181-1188.

[38] M.E. Patarroyo, M.A. Patarroyo, Emerging rules for subunit-based, multiantigenic, multistage chemically synthesized vaccines, Acc. Chem. Res. 41 (2008) 377-386.

[39] J. Baum, A.G. Maier, R.T. Good, K.M. Simpson, A.F. Cowman, Invasion by $P$. falciparum merozoites suggests a hierarchy of molecular interactions, PLoS Pathog. 1 (2005) e37.

[40] C. Geourjon, G. Deleage, SOPMA: significant improvements in protein secondary structure prediction by consensus prediction from multiple alignments, Comput. Appl. Biosci. 11 (1995) 681-684.

[41] C. Reyes, M.E. Patarroyo, L.E. Vargas, L.E. Rodriguez, M.A. Patarroyo, Functional, structural, and immunological compartmentalisation of malaria invasive proteins, Biochem. Biophys. Res. Commun. 354 (2007) 363-371.

[42] R. López, M. Urquiza, H. Curtidor, J. Eduardo Caminos, H. Mora, A. Puentes, M.E. Patarroyo, Plasmodium falciparum: red blood cell binding studies of peptides derived from histidine-rich KAHRP-I, HRP-II and HRP-III proteins, Acta Trop. 75 (2000) 349-359 